\title{
Występowanie nienasyconych kwasów tłuszczowych typu trans (elaidynowego i wakcenowego) w mleku kobiecym
}

\section{Trans fatty acids (elaidic and vaccenic) in the human milk}

\author{
Dominika Jamioł-Milc', Ewa Stachowska', Tomasz Janus², Anna Barcz³ ${ }^{3}$ Dariusz Chlubek ${ }^{4}$ \\ 'Zakład Biochemii i Żywienia Człowieka Pomorskiego Uniwersytetu Medycznego w Szczecinie \\ ul. Broniewskiego 24, 71-460 Szczecin \\ Kierownik: prof. dr hab. n. med. Ewa Stachowska
}

${ }^{2}$ Zakład Medycyny Sądowej Pomorskiego Uniwersytetu Medycznego w Szczecinie

al. Powstańców Wlkp. 72, 70-111 Szczecin

Kierownik: dr hab. n. med. Mirostaw Parafiniuk

${ }^{3}$ Zakład Matematyki Stosowanej Zachodniopomorskiego Uniwersytetu Technologicznego w Szczecinie

ul. Żołnierska 49, 71-210 Szczecin

Kierownik: dr hab. inż., prof. ZUT Andrzej Banachowicz

${ }^{4}$ Katedra Biochemii i Chemii Medycznej Pomorskiego Uniwersytetu Medycznego w Szczecinie

al. Powstańców Wlkp. 72, 70-111 Szczecin

Kierownik: prof dr hab n med. Dariusz Chlubek

\section{SUMMARY}

Introduction: The structure of trans unsaturated fatty acids (TFAs) includes at least one double bond with a trans configuration. Numerous studies have shown that TFAs influence negative changes in blood lipid profile, may initiate or accelerate the course of many inflammatory diseases, and reduce n- 6 and n-3 fatty acids' utilization. Their presence in tissues and systemic fluids is mainly the result of ingestion of TFA-containing foods.

The objective of this study was to determine the concentration profiles of elaidic and vaccenic acids in human milk, and the existence of potential correlations between the levels of trans-unsaturated fatty acids and long chain polyunsaturated fatty acids.

Materials and methods: The study group consisted of 53 lactating women, aged 18-39 years, 5-6 weeks after delivery. Elaidic and vaccenic acid levels were determined in human milk. Fatty acid methyl esters were injected onto the capillary column of an Agilent 6890M gas chromatography system integrated with an autosampler. Geometrical and positional isomers of fatty acids were identified by comparing their retention times with those of the fatty acid standards from Sigma-Aldrich. The content of individual fatty acids was determined from the reference curves and expressed in $\mathrm{mg} / \mathrm{mL}$.

Results: The level of elaidic acid was $0.2572 \pm 0.1811 \mathrm{mg} / \mathrm{mL}$, and the level of vaccenic acid was $0.2736 \pm 0.1852 \mathrm{mg} / \mathrm{mL}$. No negative correlations between the levels of the analyzed TFAs and PUFAs were observed in human milk.

Conclusions: The levels of elaidic and vaccenic acid were similar and had no negative influence on the levels of arachidonic acid and docosahexaenoic acid.

Key words: trans fatty acids, vaccenic acid, elaidic acid, human milk.

\section{STRESZCZENIE}

Wstęp: Nienasycone kwasy tłuszczowe typu trans (TFA) posiadają w swojej strukturze co najmniej jedno wiązanie podwójne o konfiguracji trans. Liczne badania dowiodły, że przyczyniają się do niekorzystnych zmian profilu lipidowego krwi, mogą inicjować lub przyspieszać przebieg wielu schorzeń o tle zapalnym, a także zmniejszać stopień wykorzystania kwasów tłuszczowych z rodziny n-6 i n-3. Obecność TFA w tkankach i płynach ustrojowych jest wynikiem przede wszystkim spożywania pokarmów posiadających w swoim składzie te kwasy tłuszczowe.

Celem pracy było określenie tego, jak kształtują się stężenia kwasu elaidynowego i wakcenowego w dojrzałym mleku kobiecym oraz ustalenie, czy istnieją zależności pomiędzy stężeniami tych dwóch TFA a stężeniami kwasów tłuszczowych z rodziny omega-3 i omega- 6 .

Materiał i metody: Badaniami objęto 53 kobiety w wieku 18-39 lat, w okresie laktacji, w 5.-6. tyg. połogu. W mleku kobiecym oznaczono zawartość kwasu elaidynowego i wakcenowego. Estry metylowe kwasów tłuszczowych nastrzykiwano na kolumnę kapilarną chromatografu gazowego 6890M Agilent wyposażonego w autosampler. Izomery geometryczne i pozycyjne kwasów tłuszczowych były identyfikowane na podstawie porównania czasów retencji z wzorcami kwasów tłuszczowych firmy Sigma-Aldrich. Zawartość poszczególnych kwasów tłuszczowych odczytywano na podstawie krzywych wzorcowych i wyrażono w mg/mL.

Wyniki: Stężenie kwasu elaidynowego kształtowało się na poziomie $0,2572 \pm 0,1811 \mathrm{mg} / \mathrm{mL}$, natomiast kwasu wakcenowego $0,2736 \pm 0,1852 \mathrm{mg} / \mathrm{mL}$. W badanym mleku kobiecym nie zaobserwowano ujemnych korelacji pomiędzy stężeniami badanych TFA a stężeniami kwasów tłuszczowych z rodziny omega-3 i omega-6.

Wnioski: Średnie stężenia kwasu elaidynowego i wakcenowego kształtowały się na podobnym poziomie i nie miały negatywnego wpływu na stężenie kwasu arachidonowego oraz kwasu dokozaheksaenowego.

Słowa kluczowe: nienasycone kwasy tłuszczowe typu trans, kwas wakcenowy, kwas elaidynowy, mleko kobiece. 


\section{WSTĘP}

Nienasycone kwasy tłuszczowe typu trans (TFA) zyskały szczególne zainteresowanie ze względu na ich związek z występowaniem schorzeń układu sercowo-naczyniowego [1, 2, 3, 4, 5]. W licznych badaniach wykazano, że TFA są najbardziej szkodliwym rodzajem kwasów tłuszczowych, a ich obecność $\mathrm{w}$ diecie powoduje zwiększenie stężenia cholesterolu frakcji LDL w osoczu z jednoczesnym obniżeniem stężenia cholesterolu frakcji HDL $[4,6,7]$. Narastanie stresu oksydacyjnego, również związane ze spożyciem TFA [8], może inicjować lub przyspieszać przebieg wielu schorzeń o tle zapalnym $[1,3,4,5$, $7,9,10,11,12,13,14,15,16,17,18]$. Nienasycone kwasy tłuszczowe typu trans zmniejszają stopień wykorzystania kwasów tłuszczowych z rodziny n-6 i n-3 w procesie syntezy prostaglandyn wykazujących właściwości przeciwzakrzepowe, ponieważ hamują aktywność $\Delta^{\circ}$-desaturazy [19, 20, 21, 22, 23, 24, 25].

Nienasycone kwasy tłuszczowe typu trans nie mogą być syntetyzowane de novo w ludzkim organizmie, z wyjątkiem kwasu wakcenowego (C18:1; trans-11) [26], zatem ich obecność w tkankach i płynach ustrojowych jest wynikiem spożywania pokarmów posiadających je w swoim składzie [8, 27]. Powstają one w wyniku przemysłowej obróbki tłuszczów roślinnych $[28,29,30]$ lub w procesie tzw. biohydrogenacji w żołądku przeżuwaczy, jak również u ludzi w jelitach przy udziale flory bakteryjnej; posiadają w swojej strukturze co najmniej jedno wiązanie podwójne o konfiguracji trans [26, 29, 31].

Produkty zawierające przemysłowo utwardzone oleje roślinne i rybie są podstawowym źródłem TFA w diecie człowieka, dostarczając ponad 60\% ich całkowitej ilości [1, 30,32]. W mleku i przetworach mlecznych oraz w mięsie udział TFA wynosi odpowiednio 30\% i 10\% ogółu kwasów tłuszczowych [1], natomiast w częściowo utwardzonych olejach roślinnych ich zawartość kształtuje się na poziomie 10-40\% [33].

Izomery trans kwasu oktadekenowego C18:1 są najpowszechniej występującymi i stanowią 80-90\% wszystkich TFA zawartych w żywności. Dominującym izomerem trans tłuszczu zwierząt przeżuwających jest kwas wakcenowy (C18:1; trans-11) stanowiący 40-80\% wszystkich izomerów trans C18:1 [8, 34], natomiast największy udział w strukturze tłuszczów produkowanych przemysłowo ma kwas elaidynowy (C18:1; trans-9) [33, 34, 35].

Celem niniejszej pracy było określenie, jak kształtują się stężenia kwasu elaidynowego i wakcenowego w dojrzałym mleku kobiecym oraz ustalenie, czy istnieją zależności pomiędzy stężeniami tych dwóch TFA a stężeniami kwasów tłuszczowych z rodziny omega-3 i omega-6.

\section{MATERIA I METODY}

\section{Charakterystyka grupy badanej}

Badaniami objęto 53 pacjentki bloku operacyjno-porodowego Kliniki Położnictwa i Perinatologii Pomorskiego Uniwersytetu Medycznego w Szczecinie (PUM)w 5.-6. tyg. połogu. Średni wiek badanych wynosił 29,11 lat.

\section{Analiza kwasów tłuszczowych}

Próbki mleka kobiecego o objętości ok. 30 mL pobierano w 5.-6. tyg. połogu za pomocą laktatora ręcznego firmy Avent w godzinach porannych, po zakończeniu karmienia. Próbki transportowano w lodzie do laboratorium Zakładu Biochemii PUM przedmuchiwano $\mathrm{w}$ atmosferze azotu, a następnie zamrażano w temperaturze $-80^{\circ} \mathrm{C}$.

Lipidy ekstrahowano z badanego materiału przy użyciu mieszaniny Folcha, a następnie hydrolizowano, otrzymując kwasy tłuszczowe, które przeprowadzano w estry metylowe (FAME) nastrzykiwane na kolumnę kapilarną (CP-SIL88 50M $\times 0,25 \mathrm{~mm}$ ID, grubość filmu 0,2 $\mu \mathrm{m}$, Varian) chromatografu gazowego 6890M Agilent wyposażonego w autosampler, gdzie FAME przemieszczały się w kolumnie $\mathrm{w}$ atmosferze wodoru jako gazu nośnego. Temperaturę początkową ustalono na $100^{\circ} \mathrm{C}$ i utrzymywano przez 1 min. Następnie temperaturę zwiększano z szybkością $10^{\circ} \mathrm{C} / \mathrm{min}$ do $180^{\circ} \mathrm{C}$, z szybkością $3^{\circ} \mathrm{C} / \mathrm{min}$ do $205^{\circ} \mathrm{C}$ i z szybkością $10^{\circ} \mathrm{C} / \mathrm{min}$ do $220^{\circ} \mathrm{C}$. Tę ostatnią temperaturę utrzymywano przez $5 \mathrm{~min}$. Temperatura detektora wynosiła $270^{\circ} \mathrm{C}$

Izomery geometryczne i pozycyjne kwasów tłuszczowych były identyfikowane na podstawie porównania czasów retencji z wzorcami kwasów tłuszczowych firmy Sigma-Aldrich. Zawartość poszczególnych kwasów tłuszczowych odczytano na podstawie krzywych wzorcowych i wyrażono w $\mathrm{mg} / \mathrm{mL}$. Oznaczenia kwasów tłuszczowych w materiale badanym przeprowadziła firma NFC sp. z o.o. w Stepnicy.

\section{Analiza statystyczna}

Uzyskane dane poddano weryfikacji metodami klasycznymi statystyki opisowej oraz matematycznej przy zastosowaniu programu Statistica. Analiza opisowa obejmowała obliczenie miar położenia (wartość najmniejsza $\mathrm{x}_{\min }$ i największa $\mathrm{x}_{\max }$, średnia arytmetyczna, mediana $\mathrm{M}_{\mathrm{e}}$, kwartyl dolny $\mathrm{Q}_{1}$ i górny $\mathrm{Q}_{2}$ ) oraz miar zróżnicowania, takich jak odchylenie standardowe i współczynnik zmienności.

Analizowane zmienne wykazywały rozkład zbliżony do normalnego, co umożliwiło dokonanie analizy korelacji polegajacej na obliczeniu współczynnika r (współczynnik korelacji Pearsona) i przeprowadzeniu testu jego istotności. Następnie porównano otrzymaną wartość z wartością krytyczną odczytaną z tablic testu t-Studenta dla n-2 stopni swobody i przyjętego poziomu istotności $\alpha$. W tabelach zebrano istotne współczynniki korelacji $(\alpha=0,05)$. Do oceny istotności różnicy średnich badanych zmiennych zastosowano metody analizy wariancji, przy czym przyjęto poziom istotności testów $\alpha=0,05$

\section{WYNIKI}

W tabeli 1 przedstawiono zmienne charakteryzujące stężenie badanych kwasów tłuszczowych w mleku kobiecym. Średnie stężenie kwasu elaidynowego i kwasu wakcenowego kształtowało się na podobnym poziomie.

W tabeli 2 przedstawiono istotne statystycznie korelacje pomiędzy stężeniami kwasu elaidynowego i wakcenowego a wielonienasyconymi kwasami tłuszczowymi (PUFA). 


\section{DYSKUSJA}

Mleko kobiece jest pierwszym pokarmem zalecanym jako podstawowy lub wyłączny przynajmniej przez pierwszych 6 miesięcy życia dziecka. W tym okresie następuje szybki wzrost niemowlęcia, a w jego organizmie gromadzi się ok. 1,4-1,7 kg tłuszczu. Jakość kwasów tłuszczowych jest bardzo istotna, ponieważ zgromadzone w tym czasie, będą podlegać przemianom metabolicznym, wykorzystywane przez rozwijający się organizm. Lipidy dostarczane z mlekiem matki, w tym również TFA, służą jako energetyczny materiał zapasowy i zapewniają utrzymanie stałej temperatury ciała. Pełnią również funkcję strukturalną jako komponenty błon komórkowych, a także są składnikiem lipidów osocza [36].

W niniejszej pracy oznaczono stężenie w mleku kobiecym dwóch izomerów TFA - kwasu elaidynowego (C18:1 trans-9) i wakcenowego (C18:1 trans-11). Ich średnie stężenia są wypadkową spożycia w okresie przedkoncepcyjnym, w okresie ciąży oraz laktacji, a w przypadku kwasu wakcenowego dodatkowo zachodzi synteza przez mikroflorę jelitową [37, 38, 39].

W obydwu przypadkach stężenia izomerów TFA charakteryzowały się znacznym zróżnicowaniem i zawierały się w przedziale 0,0552-1,1369 mg/mL w przypadku kwasu elaidynowego oraz 0,0641-1,0243 mg/mL w przypadku kwasu wakcenowego. Wyniki te potwierdzają konkluzję sformułowaną przez Ratnayake i Chena, mówiącą o tym, że stężenia TFA w mleku kobiecym mogą różnić się nawet kilkudziesięciokrotnie w badanej populacji [40]. Jest to skutek zmiennej wielkości spożycia TFA przez kobiety ciężarne i karmiące, a także ich zróżnicowanego magazynowania oraz uwalniania z adipocytów.Źródłem TFA obecnych w mleku jest z jednej strony tkanka tłuszczowa matki, w której gromadzone są kwasy tłuszczowe w postaci

TABELA 1. Stężenia badanych kwasów tłuszczowych w mleku kobiecym $(n=53)$

\begin{tabular}{lcc}
\multicolumn{1}{c}{ Zmienne } & $\begin{array}{c}\text { Kwas } \\
\text { elaidynowy }\end{array}$ & $\begin{array}{c}\text { Kwas } \\
\text { wakcenowy }\end{array}$ \\
\hline Średnia $(\mathrm{mg} / \mathrm{mL})$ & 0,2572 & 0,2736 \\
\hline Mediana $(\mathrm{mg} / \mathrm{mL})$ & 0,2380 & 0,2220 \\
\hline Minimum $(\mathrm{mg} / \mathrm{mL})$ & 0,0552 & 0,0641 \\
\hline Maksimum $(\mathrm{mg} / \mathrm{mL})$ & 1,1369 & 1,0243 \\
\hline Odchylenie standardowe $(\mathrm{mg} / \mathrm{mL})$ & 0,1811 & 0,1852 \\
\hline Dolny kwartyl $(\mathrm{mg} / \mathrm{mL})$ & 0,1495 & 0,1665 \\
\hline Górny kwartyl $(\mathrm{mg} / \mathrm{mL})$ & 0,3134 & 0,3261 \\
\hline Współczynnik zmienności (\%) & 70,4 & 67,7
\end{tabular}

triglicerydów (TG), z drugiej natomiast jej dieta w okresie laktacji $[41,42,43]$. Spadek masy ciała obserwowany u kobiety po porodzie związany jest m.in. z lipolizą wewnątrzkomórkową, w wyniku której kwasy tłuszczowe, w tym także TFA, uwalniane są z adipocytów i wykorzystywane jako substraty do syntezy lipidów w gruczole mlekowym [44]. Kwasy elaidynowy i wakcenowy mogły być więc zarówno składnikami TG w strukturze chylomikronów (po spożyciu posiłku), lipoprotein o bardzo małej gęstości (VLDL) krążących w osoczu oraz będących nośnikami TG (a tym samym TFA), jak i pochodzić z puli wolnych kwasów tłuszczowych związanych z albuminą, uwalnianych z TG adipocytów w procesie lipolizy wewnątrzkomórkowej [45]. W uwalnianiu kwasów tłuszczowych z TG frakcji lipoproteinowych (chylomikrony i VLDL) bierze udział zewnątrzkomórkowa lipaza lipoproteinowa, a reakcja lipolizy jest umiejscowiona wewnątrznaczyniowo (lipoliza wewnątrznaczyniowa). Dzięki niej wolne kwasy tłuszczowe przenikają przez barierę śródbłonkową i tkankę śródmiąższową, przedostając się do komórek wydzielniczych gruczołów sutkowych.

Istnieje hipoteza, że TFA C18:1 mogą zmniejszać aktywność desaturazy stearylo-CoA, karboksylazy acetylo-CoA i acylotransferazy w komórkach wydzielniczych gruczołów mlecznych, co skutkuje zmniejszeniem szybkości syntezy kwasów tłuszczowych de novo i syntezy TG [46].

W okresie poresorpcyjnym i w stanie głodu substraty do syntezy TG pochodzą z tkanki tłuszczowej (wolne kwasy tłuszczowe) i wątroby (zestryfikowane we frakcji VLDL) [45]. W badaniach przeprowadzonych na modelu zwierzęcym wykazano, że podczas głodzenia, gdy zmniejsza się stężenie osoczowych TG, poziom wolnych kwasów tłuszczowych ulega zwiększeniu i są one wykorzystywane do syntezy lipidów mleka. W wątrobie wolne kwasy tłuszczowe są włączane w strukturę VLDL, a w gruczole mlekowym wykorzystywane do syntezy triacylogliceroli mleka. Dlatego lipidy mleka w okresie przerwy w przyjmowaniu posiłków mają skład odpowiadający kwasom tłuszczowym zdeponowanym w tkance tłuszczowej [47].

Nie można wykluczyć, że pewien procent kwasu wakcenowego (C18:1 trans-11) uległ transformacji do kwasu rumenowego (18:2 $\Delta$ cc, 11t) przy udziale enzymu $\Delta$ 9-desaturazy związanego $\mathrm{z}$ błoną retikulum endoplazmatycznego $[48,49]$, co wpłynęło na jego stężenie w mleku.

W analizowanych próbkach mleka nie stwierdzono ujemnych korelacji pomiędzy stężeniami kwasu elaidynowego czy wakcenowego i stężeniami kwasów linolowego (LA), $\alpha$-linolenowego (ALA), $\gamma$-linolowego (GLA), arachidonowego (AA), dokozaheksaenowego (DHA) i eikozapentaenowego (EPA). Szabo i wsp. w badaniu przeprowadzonym na 769 próbkach mleka kobiecego

TABELA 2. Korelacje pomiędzy stężeniami kwasów elaidynowego i wakcenowego a stężeniami wielonienasyconych kwasów tłuszczowych w mleku kobiecym

\begin{tabular}{|c|c|c|c|c|c|c|}
\hline & C18:2 n-6 & C18:3 n-6 & C18:3 n-3 & $C 20: 4 n-6$ & $C 20: 5 n-3$ & C22:6 n-3 \\
\hline Kwas elaidynowy & 0,41 & 0,44 & 0,30 & 0,36 & ns & 0,31 \\
\hline Kwas wakcenowy & ns & 0,42 & 0,32 & 0,35 & 0,52 & 0,31 \\
\hline
\end{tabular}

ns - nieskorelowany 
wykazali istnienie odwrotnej korelacji pomiędzy stężeniami TFA C18:1 i LC-PUFA, co oznacza, że ograniczenie zawartości TFA w diecie matki może mieć związek ze zwiększeniem stężenia LC-PUFA w mleku kobiecym [50]. Jednak w próbkach pokarmu badanych przez Koletzko i wsp. nie występowały żadne zależności pomiędzy stężeniami TFA i stężeniami LA, ALA, AA i DHA [36]. Poza tym, w badaniach na modelu zwierzęcym zaobserwowano, że ekspozycja na wysokie stężenia TFA hamuje włączanie LC-PUFA do struktur fosfolipidów komórek naczyń tętniczych [51]. Przypuszcza się, że izomery trans kwasu oleinowego (C18:1), powstające w procesie hydrogenacji nienasyconych kwasów tłuszczowych olejów roślinnych, mają niekorzystny wpływ na wzrost i rozwój organizmu, ponieważ hamują proces desaturacji oraz elongacji łańcucha kwasu linolowego (C18:2 n-6) do kwasu arachidonowego (C20:4 n-6), a także przemianę kwasu $\alpha$-linolenowego (C18:3 n-3) do kwasu dokozaheksaenowego (C22:6 n-3) [19, 20, 21, 22, 23, 24, 37]. Te długołańcuchowe wielonienasycone kwasy tłuszczowe (LC-PUFA) mają wpływ m.in. na rozwój układu nerwowego [36]. Możliwe jest także, że dieta bogata w TFA jest jednocześnie uboga $w$ kwasy z rodziny n-6 i n-3, co ogranicza ich podaż [52]. Potwierdzono to $w$ badaniach in vivo na szczurach i in vitro $\mathrm{z}$ użyciem tkanek gryzoni $[22,53,54,55]$, a także w hodowlach ludzkich fibroblastów [24]. Wydaje się jednak, że stężenie TFA musi być stosunkowo wysokie (niespotykane w przeciętnej diecie człowieka), aby proces desaturacji LA ulegał zaburzeniom [56].

Prawdopodobnie z jednej strony stężenie TFA omawianych w niniejszej pracy nie było dostatecznie wysokie, aby wpływać hamująco na aktywność $\Delta^{\circ}$-desaturazy, a z drugiej strony stężenia LA i ALA osiągnęły poziom, wobec którego ewentualne hamujące działanie izomerów trans mogło się nie ujawnić. Nie jest także wykluczone, iż inne izomery trans C18:1 są silniejszymi inhibitorami w porównaniu do trans-9 i trans-11.

W badaniach własnych ujawniono natomiast istnienie dodatnich korelacji pomiędzy stężeniami kwasu elaidynowego i stężeniami LA, ALA, GLA, AA, DHA, a także pomiędzy stężeniami kwasu wakcenowego oraz stężeniami ALA, GLA, AA, DHA i EPA. Przyczyną tych wyników, odmiennych w porównaniu z badaniami innych autorów, mogą być inne założenia metodologiczne. W niniejszej pracy założono zbadanie ewentualnych zależności jedynie pomiędzy stężeniami kwasu elaidynowego i wakcenowego a PUFA. Tymczasem inne zespoły badawcze brały pod uwagę sumę TFA, a należy podkreślić, że przynajmniej 16 różnych TFA zidentyfikowano w mleku kobiecym [57]. Chociaż dominującymi TFA w diecie człowieka [58] i w mleku kobiecym [59, 60] są izomery trans C18:1, to rozszerzona analiza pozostałych TFA mogłaby wykazać zależności między konkretnym izomerem trans i danym PUFA. Przypuszczalnie uwzględnienie tych pozostałych TFA mogłoby skutkować uzyskaniem nieco odmiennych wyników korelacji.

Dostarczone z mlekiem kobiecym i wchłonięte w jelicie TFA mogą podlegać procesom $\beta$-oksydacji, zwiększaniu liczby wiązań nienasyconych, wydłużania łańcucha, a także kumulować się w tkance tłuszczowej. Wbudowywanie izomerów trans w struktury komórkowe (zwłaszcza fosfolipidy) zmienia płynność błon biologicznych, odbiór informacji przez receptory błonowe i aktywność enzymów [22, 27, 34, 61]. W porównaniu $\mathrm{z}$ izomerami cis kwasy te są w większym stopniu wbudowywane w poszczególne struktury lipidowe [62]. W wyniku badań in vitro na hodowlach enterocytów stwierdzono, że kwas elaidynowy jest włączany w TG w większym stopniu niż kwas oleinowy [63], natomiast w komórkach wątroby oba te kwasy są wbudowywane w podobnym stopniu [64, 65]. Dieta bogata w kwas elaidynowy i oleinowy powoduje większy poposiłkowy wzrost stężenia TG w porównaniu z dietą zawierającą LA i ALA [61].

Udowodniono, że dieta bogata w TFA i nasycone kwasy tłuszczowe obniża wrażliwość receptorów na insulinę, co sprzyja rozwojowi cukrzycy typu $2[13,14,66]$, przy czym zdecydowanie silniejsze działanie wykazują TFA [13]. U szczurów żywionych karmą, w której TFA stanowiły 5\% wartości energetycznej, zaobserwowano ich gromadzenie się w komórkach wątroby i trzewnej tkance tłuszczowej, czemu towarzyszyły zwiększone wartości glikemii na czczo [67].

Ekspozycja na TFA obecne w tłuszczu przeżuwaczy może stanowić ryzyko rozwoju schorzeń układu sercowo-naczyniowego w takim samym stopniu jak na TFA pozyskane na drodze przemysłowej [68], choć niektóre doniesienia wskazują na ich obojętny lub nawet pozytywny wpływ na stężenie poszczególnych frakcji lipidowych we krwi [21, 69, 70]. W wyniku badań przeprowadzonych na modelu zwierzęcym zaobserwowano, że podawany z karmą kwas wakcenowy powodował obniżenie stężenia frakcji lipidowych o działaniu aterogennym oraz hamował lipogenezę w tkance tłuszczowej [71, 72, 73, 74].

Nienasycone kwasy tłuszczowe o konfiguracji trans są związkami o udokumentowanym negatywnym wpływie na stan zdrowia, predysponującymi do rozwoju schorzeń układu sercowo-naczyniowego [1, 2, 3, 4, 5] i niektórych nowotworów $[15,16,17,18]$.

Ograniczenie spożywania pokarmów zawierających TFA w okresie laktacji nie gwarantuje ich niskiego stężenia w mleku. Natomiast, aby uchronić niemowlę przed potencjalnie niekorzystnym działaniem TFA, należy zwracać uwagę na rodzaj przyjmowanej żywności jeszcze w okresie przedkoncepcyjnym i w okresie ciąży, ponieważ okres półtrwania kwasów tłuszczowych zawartych w adipocytach wynosi ok. 680 dni [75].

\section{WNIOSKI}

Średnie stężenia badanych nienasyconych kwasów tłuszczowe typu trans w mleku kobiecym kształtowały się na podobnym poziomie, jednakże należy zaznaczyć, że stężenie kwasu elaidynowego było efektem spożywania zawierających go produktów, a w przypadku kwasu wakcenowego dodatkowo efektem syntezy przez mikroflorę jelitową oraz jego transformacji do kwasu rumenowego (obniżanie jego stężenia). Stężenia kwasu elaidynowego i wakcenowego nie wykazywały hamującego wpływu na przemiany kwasu linolowego (omega-6) oraz kwasu $\alpha$-linolenowego (omega- 3 ) oraz wbudowywanie ich metabolitów w struktury lipidów mleka. 


\section{PIŚMIENNICTWO}

1. Aro A., Amaral E., Kesteloot H., Rimestad A., Thamm van Poppel G.: Trans fatty acids in french fries, soups, and snacks from 14 European countries: The TRANSFAIR study. J Food Comp Anal. 1998, 11 (2), 170-177.

2. Aro A., Kardinaal A.F.M., Salminen I., Kark J.D., Riemersma R.A., Delgado-Rodriguez M. et al.: Adipose tissue isomeric trans fatty acids and risk of myocardial infarction in nine countries: the EURAMIC study. Lancet. 1995, 345, 273-278.

3. Hu F.B., Stampfer M.J., Manson J.E., Rimm E., Colditz G.A., Rosner B.A. et al.: Dietary fat intake and the risk of coronary heart disease in women. $\mathrm{N}$ Engl J Med. 1997, 337 (21), 1491-1499.

4. Mensink R.P., Zock P.L., Kester A.D., Katan M.B.: Effects of dietary fatty acids and carbohydrates on the ratio of serum total HDL cholesterol and on serum lipids and apolipoproteins: a meta analysis of 60 controlled trials. Am J Clin Nutr. 2003, 77 (5), 1146-1155.

5. Roberts T.L., Wood D.A., Reimersma R.A., Gallagher P.J., Lampe F.C.: Trans isomers of oleic and linoleic acids in adipose tissue and sudden cardiac death. Lancet. 1995, 345 (8945), 278-282.

6. Judd J.T., Clevidence B.A., Muesing R.A., Wittes J., Sunkin M.E., Podczasy J.J.: Dietary trans fatty acids: effects on plasma lipids and lipoproteins of healthy men and women. Am J Clin Nutr. 1994, 59 (4), 861-868.

7. Katan M.B., Zock P L., Mensink R.P.: Trans fatty acids and their effects on lipoproteins in humans. Annu Rev Nutr. 1995, 15, 473-493.

8. Kuhnt K., Wagner A., Kraft J., Basu S., Jahreis G.: Dietary supplementation with 11 trans and 12 trans 18:1 and oxidative stress in humans. Am J Clin Nutr. 2006, 84 (5), 981-988.

9. Troisi R., Willett W.C., Weiss S.T.: Trans fatty acid intake in relation to serum lipid concentrations in adult men. Am J Clin Nutr. 1992, 56 (6), 1019-1024.

10. Lopez-Garcia E., Schulze M.B., Meigs J.B., Manson J.E., Rifai N., Stampfer M.J. et al:: Consumption of trans fatty acids is related to plasma biomarkers of inflammation and endothelial dysfunction. J Nutr. 2005, 135 (3), 562-566.

11. Mozaffarian D., PischonT., Hankinson S.E., Rifai N., Joshipura K., Willett W.C. et al.: Dietary intake of trans fatty acids and systemic inflammation in women. Am J Clin Nutr. 2004, 79 (4), 606-612.

12. Mozaffarian D., Rimm E.B., King I.B., Lawler R.L., McDonald G.B., Levy W.C.: Trans fatty acids and systemic inflammation in heart failure. Am J Clin Nutr. 2004, 80 (6), 1521-1525.

13. Ibrahim A., Natrajan $S$., Ghafoorunissa R.: Dietary trans-fatty acids alter adipocyte plasma membrane fatty acid composition and insulin sensitivity in rats. Metabolism. 2005, 54 (2), 240-246.

14. Salmeron J., Hu F.B., Manson J.E., Stampfer M.J., Colditz G.A., Rimm E.B. et al.: Dietary fat intake and risk of type 2 diabetes in women. Am J Clin Nutr. 2001, 73 (6), 1019-1026.

15. King I.B., Kristal A.R., Schaffer S., Thornquist M., Goodman G.E.: Serum trans fatty acids are associated with risk of prostate cancer in beta-carotene and retinol efficacy trial. Cancer Epidemiol Biomarkers Prev. 2005, 14 (4), 988-992.

16. Kohlmeier L., Simonsen N., van't Veer P., Strain J.J., Martin-Moreno J.M., Margolin B. et al:: Adipose tissue trans fatty acids and breast cancer in the European community. Multicenter study on antioxidants, myocardial infarction and breast cancer. Cancer Epidemiol Biomarkers Prev. 1997, $6(9), 705-710$.

17. Liu X., Schumacher F.R., Plummer S.J., Jorgenson E., Casey G., Witte J.S.: Trans fatty acid intake and increased risk of advanced prostate cancer: modification by RNASEL R462Q variant. Carcinogenesis. 2007, 28 (6), 1232-1236.

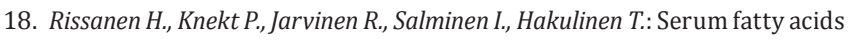
and breast cancer incidence. Nutr Cancer. 2003, 45 (2), 168-175.

19. Cook H.W., Emken E.A.: Geometric and positional fatty acid isomers interact differently with desaturation and elongation of linoleic and linolenic acids in cultured glioma cells. Biochem Cell Biol. 1990, 68 (3), 653-660.

20. De Schrijver R., Privett O.S.: Interrelationship between dietary trans fatty acids and the 6- and 9-desaturases in the rat. Lipids. 1982, 17 (1), 27-34.

21. Kurata N., Privett O.S.: Effects of dietary trans acids on the biosynthesis of arachidonic acid in rat liver microsomes. Lipids. 1980, 15 (12), 1029-1036.
22. Larque E., Garcia-Ruiz P.A., Perez-Llamas F., Zamora S., Gil A.: Dietary trans fatty acids alter the compositions of microsomes and mitochondria and the activities of microsome delta6-fatty acid desaturase and glucose-6-phosphatase in livers of pregnant rats. J Nutr. 2003, 133 (8), 2526-2531.

23. Larque E., Perez-Llamas F., Puerta V., Giron M.D., Suarez M.D., Zamora S. et al.: Dietary trans fatty acids affect docosahexaenoic acid concentrations in plasma and liver but not brain of pregnant and fetal rats. Pediatr Res. 2000, 47 (2), 278-283.

24. Rosenthal M.D., Doloresco M.A.: The effects of trans fatty acids on fatty acyl delta 5 desaturation by human skin fibroblasts. Lipids. 1984, 19 (11), 869-874.

25. Stachowska E., Dołęgowska B., Chlubek D., Wesołowska T., Ciechanowski K., Gutowski P. et al.: Dietary trans fatty acids composition of human atheromatous plaques. Eur J Nutr. 2004, 43 (5), 313-318.

26. Devillard E., McIntosh F.M., Duncan S.H., Wallace R.J.: Metabolism of linoleic acid by human gut bacteria: different routes for biosynthesis of conjugated linoleic acid. J Bacteriol. 2007, 189 (6), 2566-2570.

27. Holman R.T., Pusch F., Svingen B., Dutton H.J.: Unusual isomeric polyunsaturated fatty acids in liver phospholipids of rats fed hydrogenated oil. Proc Natl Acad Sci USA. 1991, 88 (11), 4830-4834.

28. Hunter J.E.: Dietary trans fatty acids: review of recent human studies and food industry responses. Lipids. 2006, 41 (11), 967-992.

29. Martin C.A., Milinsk M.C., Visentainer J.V., Matsushita M., de-Souza N.E.: Trans fatty acid-forming processes in foods: a review. An Acad Bras Cienc. 2007, 79 (2), 343-350.

30. Mosley E.E., Powell G.L., Riley M.B., Jenkins T.C.: Microbial biohydrogenation of oleic acid to trans isomers in vitro. J Lipid Res. 2002, 43 (2), 290-296.

31. Botham K.M., Mayes P.A.: Lipidy o znaczeniu fizjologicznym. In: Biochemia Harpera. Eds. R.K. Murray. PZWL, Warszawa 2008, 149-161.

32. Innis S.M., Green T.J., Halsey T.K.: Variability in the trans fatty acid content of foods within a food category: implications for estimation of dietary trans fatty acid intakes. J Am Coll Nutr. 1999, 18 (3), 255-260.

33. Gebauer S.K., Psota T.L., Kris-Etherton P.M.: The diversity of health effects of individual trans fatty acids isomers. Lipids. 2007, 42 (9), 787-799.

34. Kraft J., Hanske L., Mockel P., Zimmermann S., Hartl A., Kramer J.K. et al.: The conversion efficiency of trans-11 and trans-12 18:1 by delta 9-desaturation differs in rats. J Nutr. 2006, 136 (5), 1209-1214.

35. Wolff R.L., Precht D.: Reassessment of the contribution of bovine milk fats to the trans-18:1 isomeric acid consumption by European populations. Additional data for rumenic (cis-9, trans-11 18:2) acid. Lipids. 2002, 37 (12), 1149-1150.

36. Koletzko B., Mrotzek M., Bremer H.J.: Fatty acids composition of mature human milk in Germany. Am J Clin Nutr. 1988, 47 (6), 954-959.

37. Del Prado M., Villalpando S., Elizondo A., Rodriguez M., Demmelmair H., Koletzko B.: Contribution of dietary and newly formed arachidonic acid to human milk lipids in women eating a low-fat diet. Am J Clin Nutr. 2001, 74 (2), 242-247.

38. Tinoco S.M., Sichieri R., Setta C.L., Moura A.S., do Carmo M.G.: Trans fatty acids from milk of Brazilian mothers of premature infants. J Paediatr Child Health. 2008, 44 (1-2), 50-56.

39. Daud A.Z., Mohd-Esa N., Azlan A., Mun Chan Y.: The trans fatty acid content in human milk and its association with maternal diet among lactating mothers in Malaysia. Asia Pac J Clin Nutr. 2013, 22 (3), 431-442.

40. Ratnayake W.M., Chen Z.Y.: Trans, n-3, and n-6 fatty acids in Canadian human milk. Lipids. 1996, 31 (Suppl.), S279-S282.

41. Silber G., Hachey D.L., Schanler R., Garza C.: Manipulation of the maternal diet to alter fatty acid composition of human milk intended for premature infants. Am J Clin Nutr. 1988, 47 (5), 810-814.

42. Neville M.C.: Regulation of milk fat synthesis. J Pediatr Gastroenterol Nutr. 1989, 8 (4), 426-429.

43. Hachey D.L., Thomas M.R., Emken E.A., Garza C., Brown-Booth L., Adlof R.O. et al: Human lactation: maternal transfer of dietary triglycerides labeled with stable isotopes. J Lipid Res. 1987, 28 (10), 1185-1192.

44. Chappell J.E., Clandinin M.T., Kearney-Volpe C.: Trans fatty acids in human milk lipids: influence of maternal diet and weigh loss. Am J Clin Nutr. 1985, 42 (1), 49-56.

45. Neville M.C., Picciano M.F.: Regulation of milk lipid secretion and composition. Annu Rev Nutr. 1997, 17, 159-184.

46. Gaynor P.J., Waldo D.R., Capuco A.V., Erdman R.A., Douglass L.W., Teter B.B.: Milk fat depression, the glucogenic theory and trans C18:1 fatty acids. J Dairy Sci. 1995, 78 (9), 2008-2015. 
47. Rudolph M.C., Neville M.C., Anderson S.M.: Lipid synthesis in lactation: diet and the fatty acid switch. J Mammary Gland Neoplasia. 2007, 12 (4), 269-281.

48. Turpeinen A.M., Mutanen M., Aro A., Salminen I., Basu S., Palmquist D.L. et al.: Bioconversion of vaccenic acid to conjugated linoleic acid in humans. Am J Clin Nutr. 2002, 76 (3), 504-510.

49. Niwińska B.: Endogenous synthesis of rumenic acid in humans and cattle. J Animal Feed Sci. 2010, 19, 171-182.

50. Szabo E., Boehm G., Beermann C., Weyermann M., Brenner H., Rothenbacher D. et al: Trans octadecenoic acid and trans octadecadienoic acid are inversely related to long-chain polyunsaturates in human milk: results of a large birth cohort study. Am J Clin Nutr. 2007, 85 (5), 1320-1326.

51. Kummerow F.A., Zhou Q., Mahfouz M.M., Smiricky M.R., Grieshop C.M., Schaeffer D.J.: Trans fatty acids in hydrogenated fat inhibited the synthesis of the polyunsaturated fatty acids in the phospholipid of arterial cells. Life Sci. 2004, 74 (22), 2707-2723.

52. Innis S.M., King D.J.: Trans fatty acids in human milk are inversely associated with concentrations of essential all cis n- 6 and n-3 fatty acids and determine trans, but not n- 6 and n-3 fatty acids in plasma lipids of breast-fed infants. Am J Clin Nutr. 1999, 70 (3), 383-390.

53. Lawson L.D., Hill E.G., Holman R.T.: Suppression of arachidonic acid in lipids of rat tissues by dietary mixed isomeric cis and trans octadecenoates. J Nutr. 1983, 113 (9), 1827-1835.

54. Lippi G., Albiero A., Montagnana M., Salvagno G.L., Scevarolli S., Franchi M. et al: Lipid and lipoprotein profile in physiological pregnancy. Clin Lab. 2007, 53 (3-4), 173-177.

55. Hill E.G., Johnson S.B., Lawson L.D., Mahfouz M.M., Holman R.T.: Perturbation of the metabolism of essential fatty acids by dietary partially hydrogenated vegetable oils. Proc Natl Acad Sci USA. 1982, 79 (4), 953-957.

56. Zevenbergen J.L., Houtsmuller U.M., Gottenbos J.J.: Linoleic acid requirement of rats fed trans fatty acids. Lipids. 1988, 23 (3), 178-186.

57. Mosley E.E., Wright A.L., McGuire M.K., McGuire M.A.: Trans fatty acids in milk produced by women in the United States. Am J Clin Nutr. 2005, 82 (6), 1292-1297.

58. van de Vijver L.P., Kardinaal A.F., Couet C., Aro A., Kafatos A., Steingrimsdottir L. et al: Association between trans fatty acid intake and cardiovascular risk factors in Europe: the TRANSFAIR study. Eur J Clin Nutr. 2000, 54 (2), 126-135.

59. Glew R.H., Cole D.M., Mehla G.S., El-Nafaty A.U., Crossey M.J., Tzamaloukas A. et al.: Lysosomal enzymes in preeclamptic women in northern Nigeria. Clin Chim Acta. 2005, 353 (1-2), 95-101.

60. Larque E., Zamora S., Gil A.: Dietary trans fatty acids in early life: a review. Early Hum Dev. 2001, 65 (Suppl. 2), 31-41.

61. McCloy U., Ryan M.A., Pencharz P.B., Ross R.J., Cunnane S.C.: A comparison of the metabolism of eighteen-carbon 13C-unsaturated fatty acids in healthy women. J Lipid Res. 2004, 45 (3), 474-485.

62. Koletzko B.: Trans fatty acids may impair biosynthesis of long chain polyunsaturates and growth in man. Acta Paediatr. 1992, 81 (4), 302-306.
63. van Greevenbroek M.M., Robertus-Teunissen M.G., Erkelens D.W., de Bruin T.W.: Lipoprotein secretion by intestinal Caco- 2 cells is affected differently by trans and cis unsaturated fatty acids: effect of carbon chain length and position of the double bond. Am J Clin Nutr. 1998, 68 (3), 561-567.

64. Dashti N., Feng Q., Franklin F.A.: Long-term effects of cis and trans monounsaturated (18:1) and saturated (16:0) fatty acids on the synthesis and secretion of apolipoprotein A-I- and apolipoprotein B-containing lipoproteins in HepG2 cells. J Lipid Res. 2000, 41 (12), 1980-1990.

65. Guzman M., Klein W., Gomez del Pulgar T., Geelen M.J.: Metabolism of trans fatty acids by hepatocytes. Lipids. 1999, 34 (4), 381-386.

66. Christiansen E., Schnider S., Palmvig B., Tauber-Lassen E., Pedersen O.: Intake of a diet high in trans monounsaturated fatty acids or saturated fatty acids. Effects on postprandial insulinemia and glycemia in obese patients with NIDDM. Diabetes Care. 1997, 20 (5), 881-887.

67. Lessa N.M., Nakajima V.M., Matta S.L., Peluzio M.C., Sabarense C.M., Costa N.M.: Deposition of trans fatty acid from industrial sources and its effect on different growth phases in rats. Ann Nutr Metab. 2010, 57 (1), 23-34.

68. Rice B.H., Kraft J., Destaillats F., Bauman D.E., Lock A.L.: Ruminant-produced trans-fatty acids raise plasma total and small HDL particle concentrations in male Hartley guinea pigs. J Nutr. 2010, 140 (12), 2173-2179.

69. Tholstrup T., Raff M., Basu S., Nonboe P., Sejrsen K., Straarup E.M.: Effects of butter high in ruminant trans and monounsaturated fatty acids on lipoproteins, incorporation of fatty acids into lipid classes, plasma C-reactive protein, oxidative stress, hemostatic variables, and insulin in healthy young men. Am J Clin Nutr. 2006, 83 (2), 237-243.

70. Motard-Belanger A., Charest A., Grenier G., Paquin P., Chouinard Y., Lemieux S. et al:: Study of the effect of trans fatty acids from ruminants on blood lipids and other risk factors for cardiovascular disease. Am J Clin Nutr. 2008, 87 (3), 593-599.

71. Tyburczy C., Major C., Lock A.L., Destaillats F., Lawrence P., Brenna J.T. et al.: Individual trans octadecenoic acids and partially hydrogenated vegetable oil differentially affect hepatic lipid and lipoprotein metabolism in golden Syrian hamsters. J Nutr. 2009, 139 (2), 257-263.

72. Lock A.L., Horne C.A., Bauman D.E., Salter A.M.: Butter naturally enriched in conjugated linoleic acid and vaccenic acid alters tissue fatty acids and improves the plasma lipoprotein profile in cholesterol-fed hamsters. J Nutr. 2005, 135 (8), 1934-1939.

73. Faulconnier Y., Roy A., Ferlay A., Chardigny J.M., Durand D., Lorenz S. et al.: Effect of dietary supply of butters rich either in trans-10-18:1 or in trans-11-18:1 plus cis-9, trans-11-18:2 on rabbit adipose tissue and liver lipogenic activities. Br J Nutr. 2006, 96 (3), 461-468.

74. Bauchart D., Roy A., Lorenz S., Chardigny J.M., Ferlay A., Gruffat D. et al.: Butters varying in trans 18:1 and cis-9, trans-11 conjugated linoleic acid modify plasma lipoproteins in the hypercholesterolemic rabbit. Lipids. 2007, 42 (2), 123-133.

75. Sun Q., Ma J., Campos H., Hankinson S.E., Hu F.B.: Comparison between plasma and erythrocyte fatty acid content as biomarkers of fatty acid intake in US women. Am J Clin Nutr. 2007, 86 (1), 74-81. 